\title{
THE PAYEE AS A HOLDER IN DUE COURSE
}

\author{
Wiltiaar E. Britton*
}

$7 \mathrm{HE}$ most conspicuous characteristic of negotiable paper is its transferability free from equities and defenses. This preferred position is given to the innocent purchaser for value and before maturity. Normally the payee, because he deals with the maker or drawer, cannot be a holder in due course, because the facts which create the defense or equity will be of his own creation. But it is possible for the payee to be insulated from these facts. In the rare case where he is ignorant of them, should he be treated the same as the law would treat a technical indorsee for value and without notice of the defense?

The problem as to whether a payee can be a holder in due course owes its origin to the peculiar wording of several sections of the Negotiable Instruments Law. A substantial number of decisions before the Act indicates that at common law there was nothing in the position of the payee as such which made it impossible for him to be a holder in due course. ${ }^{x}$ But the courts have disagreed in their construction of the applicable sections of the Negotiable Instruments Law to the problem here raised.

The Sections involved are: 52, 30, I4, I6, and the definitions of "Holder" and "Issue" in Section I9I. There is nothing in Section $5^{2}$ (r), (2), and (3) which in any way tends to exclude a payee from the position as a holder in due course. So far as appears from any of these three subsections the entire question as to whether the payee can be a holder in due course is a question largely of fact, i.e., was he a holder, was the instrument complete and regular, did he purchase before maturity and did he take in good faith? That the payee is a "holder" is obvious from the definition contained in Section I9I, which reads: "Holder means the payee or indorsee of a bill or note, who is in possession of it, or the bearer thereof." And "bearer" is defined as "the person in possession of a bill or note which is payable to bearer."

* Professor of Law, University of Illinois.

I Aigler, Payees as Holders in Due Course, 36 Yale L.Jour. 608, 619, n. 39 (1927), citing the following cases: Armstrong v. American Exchange Nat. Bank, I33 U.S. 433, Io Sup. Ct. 450 , 33 L.Ed. 747 ( 1890 ); Cagle v. Lane, 49 Ark. 465 (I887); So. Boston Iron Co. v. Brown, 63 Me. r39 (I873); Glasscock v. Rand, $x_{4}$ Mo. $55^{\circ}$ (1851); Jordan v. Jordan, 78 Tenn. I24 (I882); Lookout Bank v. Aull, 93 Tenn. 645, 27 S.W. IOI4 (I894); Passumpsic Bank v. Goss, 3 I Vt. 3 I 5 (x858); Dixon v. Dixon, 3 I Vt. 450 (I859); F. \& M. Bank v. Humphrey, 36 Vt. 554 (I864); Frank \& Adler v. Lilienfeld, 33 Gratt. (Va.) 377 (1880). 
There has never been any suggestion that a payee could not be a holder in due course because of anything contained in Section $5^{2}$ (I), (2) or (3). But the main argument that the payee cannot be a holder in due course is that Section $5^{2}(4)$, and other sections, prescribe that a person to be a holder in due course must not only have taken the instrument for value, in good faith and before maturity, but also that he must have acquired the instrument by "negotiation." This argument is not without force. Section $5^{2}$ (4), repeating in part the substance of Section $5^{2}$ (3), requires as a condition of one's being a holder in due course, "that at the time it was negotiated to him he had no notice of any infirmity in the instrument or defect in the title of the person negotiating it." Again, Section I4, in prescribing the effect of an instrument's being executed and delivered blank as to some material particular, provides: "But if any such instrument, after completion, is negotiated to a holder in due course, it is valid and effectual for all purposes in his hands, and he may enforce it as if it had been filled up strictly in accordance with the authority given and within a reasonable time." The negative implication from Section $5^{2}(4)$ and Section $I_{4}$ is that if the instrument was acquired by the one claiming protection by some process other than a "negotiation," such party could not be a holder in due course.

A similar implication arises from Section 16 which deals with the effect of the non-delivery of a completed instrument. The section provides that "where the instrument is in the hands of a holder in due course, a valid delivery thereof by all parties prior to him so as to make them liable to him is conclusively presumed." But the section also states the converse of the proposition last stated by saying that "as between immediate parties, and as regards a remote party other than a holder in due course, the delivery, in order to be effectual, must be made either by or under the authority of the party making, drawing, accepting, or indorsing, as the case may be; and in such case the delivery may be shown to have been conditional, or for a special purpose only, and not for the purpose of transferring the property in the instrument." The section speaks as though there were an insuperable obstacle to one's being a holder in due course if he were an "immediate party" with respect to the maker or drawer.

Thus the question as to whether the payee may be a holder in due course seems to turn on the question as to whether the payee takes by "negotiation" and whether the payee and the maker or drawer are "immediate parties" within the meaning of the sections referred to.

Section 30 defines a negotiation as follows: "An instrument is negoti- 
ated when it is transferred from one person to another in such manner as to constitute the transferee the holder thereof." Thus far the payee fulfils the conditions of this section because he is a "holder" under Section I9x. But the section adds: "If payable to bearer it is negotiated by delivery; if payable to order it is negotiated by the indorsement of the holder completed by delivery." The implication is that the only person who may negotiate an instrument is a "holder," and the maker or drawer certainly does not fall within the definition of "holder." This implication from Section 30 is confirmed by the definition of the term "issue" in Section I9I which reads: "Issue' means the first delivery of the instrument, complete in form, to a person who takes it as a holder."

Thus, the definition of "negotiation" and of "issue" are quite consistent. Under the definition of "delivery" in Section I9I which "means transfer of possession, actual or constructive, from one person to another" it is apparent that there can be a delivery to one who does not take as holder. But, if a delivery is to amount to an issuance, the instrument must be delivered to one who takes as holder. Hence it is correct to speak of a transfer of an instrument by the maker or drawer to a third party other than a holder, to be by him handed to the payee as a "delivery" under Section Igr, but such an instrument is not issued until it is in the hands of one who takes as holder. The above general set of facts is the normal situation which brings up the problem as to whether a payee may be a holder in due course. It is clear that the payee takes by issuance, and not by negotiation, at least on a literal interpretation of the sections quoted, and without taking into consideration the qualification to all definitions contained in Section I9I, i.e., that the terms therein defined are to be construed as such "unless the context otherwise requires." The courts that have held that a payee cannot be a holder in due course have relied upon the reasoning outlined above either in whole or in part. ${ }^{2}$

${ }^{2}$ In Herdman v. Wheeler, [rgo2] I K.B. 36 I and Lewis v. Clay, 77 L.T.N.S. 653 (1897) it was apparently the view of the court that the payee could not be a holder in due course. But in Lloyds Bank v. Cooke, [xgo7] I K.B. 794, a contrary result was reached, but the payee here may have been protected on the principle of estoppel. And along this line see Smith v. Prosser, [1907] 2 K.B. 735; Glennie v. Bruce Smith, [1908] I K.B. 263; and Talbot v. Von Boris, [I9II] I K.B. 854. Above cases discussed by A. M. Hamilton in 24 Jur. Rev. 4I (IgI2); the writer favors the view that the payee should not be treated as a holder in due course. And by Professor Feezer in his article in 9 Minn. L. Rev. Ior, ro5-IrI (I925), who takes the contrary view. In Jones v. Waring, [1925] 2 K.B. 6I2, the Court of Appeal proceeded on the theory that a payee could be a holder in due course, but this decision was reversed by the House of Lords, [1926] A.C. 670. The decision cannot be taken to establish the law in England that a payee cannot be a holder in due course. While the judges stated that a payee could not be a holder in due course, the issue was decided mainly on other grounds. Disapproved in 25 Mich. L. Rev. 535 (I927). Plaintiff's right to recover on quasi-contract grounds disapproved in $x x$ Minn. L. Rev. 384 ( 1927 ), and 75 Univ. Pa. L. Rev. 274 (I927). See further comment on this case in 40 Harv. L. Rev. 494 (1927), and 36 Yale L. Jour. I005 ( 1927$)$. The English cases are discussed by Pro- 
But while this argument has a persuasive appeal there is an entirely different construction that can be placed upon these sections. In the first place it should be noted that Section $5^{2}$ undertakes to prescribe the gen-

fessor Aigler in his article, Payees as Holders in Due Course, 36 Yale L. Jour. 608, 6r 3-6rg (1927), in which he concludes that "'the generality of the language as to the situation of a payee under the Bills of Exchange Act leaves it very difficult for any other and therefore inferior English court to reach what is believed to be the sound conclusion," i.e., that a payee may be a holder in due course.

Davis v. Nat. City Bank of Rome, 167 S.E. I9I (Ga. App. I932) holds that a payee cannot be a holder in due course with a full discussion of the question.

In Vander Ploeg v. Van Zuuk, 135 Iowa 350, Ir 2 N.W. 807 ( 1907 ), defendants signed a note blank as to the amount and payee's name, as accommodation makers for the partner of one of them. Plaintiff's name was inserted as payee and the instrument was delivered in violation of the agreement with the defendants. Directed verdict for defendant was affirmed. The court held that under Sections $5^{2}$ and $x_{4}$ the payee could not be a holder in due course because the term holder in due course thereunder "seems unquestionably to be used to indicate a person to whom after completion and delivery the instrument has been negotiated." The court distinctly refused to say that under no circumstances could the payee be a holder in due course. The court said (I35 Iowa at 535): "We do not mean to say that in no case can the person named as payee in a negotiable instrument be the holder thereof 'in due course.' If $A$, purchasing a draft to be transmitted to $B$ in payment of $A$ 's debt to $B$, causes the draft to be payable to $B$ no doubt $A$ is the holder of such draft, and $B$ taking it for value becomes a holder in due course. ... . No doubt the payee named in a promissory note might under similar circumstances be a holder in due course." The court says this result cannot be reached here "for the check was not delivered by the drawer as a valid and complete instrument to the person intrusted with it, but it was given into his hands only for delivery to the payee in extinguishment of the drawer's debt to the payee. . . . . Before such delivery the person intrusted with it was not a holder."

Followed in Builders' Lime \& Cement Co. v. Weimer, 170 Iowa 144, 150 N.W. 100 (1915); Devoy \& Kuhn Coal \& Coke Co. v. Huttig, I 74 Iowa 357, $x 56$ N.W. 4I3 (I9r6). The court here refused to overrule Vander Ploeg v. Van Zuuk, supra, despite the subsequent cases of Lloyds Bank v. Cooke, supra, and Smith v. Prosser, supra, which seemed to discredit the prior cases of Lewis v. Clay, supra, and Herdman v. Wheeler, supra, on which the Iowa court relied in part in Vander Ploeg v. Van Zuuk, supra. In none of these cases was there any re-examination of the question.

In Farmers' Savings Bank of Ruthven v. Grange, x99 Iowa 978, 203 N.W. 37 (1925) where a third party obtained the defendant's note by fraud, the same being payable to plaintiff bank, which took said note as collateral security for the bank's loan of the same amount to the one who procured the note, it was held, without citation of any authority or any discussion of the problem as to the payee's status as a holder in due course, that plantiff could recover from the maker free from his defense of fraud. The same method was pursued in allowing the payee to recover in Commercial State Bank of Britt v. Beers, I99 Iowa 864, 202 N.W. 757 (1925). And see also Marion Sav. Bank v. Leahy, 2co Iowa 220, 204 N.W. 456 (I925), and Henderson v. Holt, 20x Iowa 10r 7, 206 N.W. ז34 (r925).

Southern Nat. Life Realty Corp. v. People's Bank, r78 Ky. 80, r98 S.W. 543 (I917). Payee not a holder in due course because one may be such only when the instrument has been negotiated to him and a payee takes not by negotiation but by issuance as defined in Section Igr. Surety's special defense of release of security by the payee to the principal debtor a good defense.

But Thompson v. Peck, 217 Ky. 766 , 29o SW. 722 (x927) while not a definite adverse holding to the above case, was disposed of in such a manner as to raise the question whether the earlier case would necessarily be followed.

The Missouri cases seem to hold that a payee cannot be a holder in due course, though other 
eral situation of fact which must be present before a holder has a right to recover thereon free from equities of defense and equities of ownership. These general requirements are three: purchase in good faith, before maturity and for value. These are set forth in sub-sections (I), (2) and

factors in the cases account for the specific results reached. St. Charles Savings Bank v. Edwards, 243 Mo. 553, $x_{47}$ S.W. 978 (rgI 2); Long v. Mason, 273 Mo. 266, 200 S.W. x062 (Igr8), affg. I 85 Mo. App. 64x, I7 I S.W. 690 (I9r4); Gates City Nat. Bank v. Burton, 3 16 Mo. I338, 296 S.W. 375 (I927). The latter case was disapproved in 76 Univ. Pa. L. Rev. 204 (IgI7), wherein the writer takes the position that the question as to whether the payee could not be a holder in due course was not properly involved. And see also Canada v. Shuttee, 2ro Mo. App. $6{ }_{4},{ }_{235}$ S.W. 824 (I922) and Mutual Life of Illinois v. McKinnis, I5 S.W. (2d) 935 (Mo. App. I929); Bolton v. Wharton, 136 S.C. 242, 16r S.E. 454 (193 I) (dictum payee not a holder in due course).

In Hathaway v. Delaware County, 185 N.Y. 368,78 N.E. $5_{53}$ (I906), while the point was not discussed, the view taken was consistent with that which denies to a payee the status of a holder in due course. In Brown v. Rowan, 9I Misc. 220, 154 N.Y.S. Iog8 (19 5 ) the court took the view that a payee could be a holder in due course. Accord: Bergstrom v. Ritz-Carlton Restaurant \& Hotel Co., 17 I App. Div. 776, I57 N.Y.S. 959 (IgI6). A contrary view is expressed in Miller v. Campbell, I73 App. Div. 821, I60 N.X.S. 834 (I9I6). The point was involved and discussed at length in Empire Trust Co. v. President and Directors of Manhattan Co., 97 Misc. 694, I62 N.Y.S. 629 (I916), affd. without opinion in r80 App. Div. 89r, r66 N.Y.S. $\mathrm{x}_{093}$ (IgI7). The court here approves generally the policy of protecting some payees as holders in due course, but denies protection to the payee in the case at bar for the reason that the third party, a thief, who transferred a certified check stolen from the certifying bank, to the payee was one who had not obtained it by the voluntary act of the drawer. The case is disapproved in 30 Harv. L. Rev. 515 ( 1917 ). The case is approved in $20 \mathrm{Col}$. L. Rev. 749, 760 (I920), by Professor Moore on the ground that the thief presented himself to the payee not as a remitter but as agent for the drawer.

In Potts v. First State Bank of Talihina, 5 I Okla. I62, $15 \times$ Pac. 859 ( $\left.19 x_{5}\right)$ the payee was allowed to recover from a surety maker whose signature was obtained by fraud of the principal debtor. There was no discussion of the Negotiable Instruments Law or citation of cases on the point. Cited with approval in Citizens' State Bank v. Cressler, 69 Okla. 68, 170 Pac. 230 (I9I7). But in First Nat. Bank of Poteau v. Allen, 88 Okla. I62, 2I2 Pac. 597 (I923) where an agent of the payee, for his own purposes, fraudulently obtained the defendants' note, it was held that the payee could not recover. The court, upon the assumption that the holder could be a holder in due course, found that the payee was not such, because it parted with no value. No discussion of the sections or cases on the point. In Strother v. Wilkinson, 90 Okla. 247, 216 Pac.

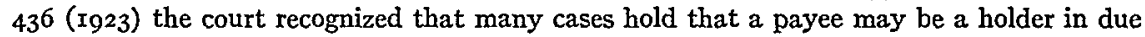
course, but stated that First Nat. Bank of Poteau v. Allen, supra, had held the contrary, a decision here followed. In Rice v. Jones, xo2 Okla. 30, 225 Pac. 958 (I924), the court adhered to that rule that a payee could not be a holder in due course, with a full citation of authorities on both sides of the controversy. Payee here denied the right to recover upon a materially altered instrument according to its original tenor. Accord: Farmers' State Bank of Afton v. Mowry, I07 Okla. 275, 232 Pac. 26 ( r $_{925}$ ) but the court refers to Potts v. First State Bank of Talihina, supra, with approval. In Bond v. Krugg, Ix5 Okla. 202, 242 Pac. 559 (x925) the payee was allowed to recover from the drawer free from a possible personal defense, although the court viewed the case as one not involving the law of negotiable instruments. And at the same time the court said that the payee could not be a payee in due course and this question was "no longer open." See also First Nat. Bank of Westville v. Russell, I28 Okla. 222, 262 Pac. 205 (r927).

The South Dakota cases are in accord with those cases where the instrument was procured 
(3). In reality all three requirements are contained in sub-sections (2) and (3) of Section 54. The importance to be attached to this observation is that nowhere in the language which sets forth these general requirements of good faith purchase for value and before maturity is there the slightest intimation that a payee could not be a holder in due course. Nor has it ever been so contended. The whole argument that the payee cannot be a holder in due course is predicated upon Section 52 (4) which seems to require by implication, that only those holders can be holders in due course who take by negotiation. This implication is by no means mandatory for these reasons. Section $5^{2}$ (3), in laying down the rule of purchase in good faith simply says that the requirement is "that he took it in good faith." One may "take" an instrument by issuance as well as by "negotiation." A broader term could scarcely have been used. The framers of the Act carefully avoided the use of terms having technical significations such as that of "negotiation" or "issue." The language of Section $52(3)$, because it is laying down the general rule should be the determining factor in the problem of construction here raised.

An examination of Section $5^{2}$ (I) and Section $5^{2}$ (4), shows that the use of the term "negotiation" in the latter sub-section was never intended to introduce the further requirement that a holder, to be a holder in due

by the fraud of a third party. But the court has stated its approval of cases holding that a payee may be a holder in due course, wherever it can find facts sufficient to constitute an estoppel. The following cases would therefore not necessarily be authority in a case where an agent of the maker fraudulently diverted the instrument or any other case where an estoppel could be found. In Britton Milling Co. v. Williams, 44 S.D. 464 , I84 N.W. 265 (I92I), 45 S.D. 274, I87 N.W. 159 (1922) where a third party fraudulently obtained a note signed by the defendant as maker, and transferred to the payee, who took for value and in good faith, the court held that the payee could not be a holder in due course because Section 52 (4) "contemplates that to be a holder in due course the holder must have acquired the note by 'negotiation' . . . . and not by 'issue'" as was done in this case. However, judgment for defendant having been rendered by the trial court on directed verdict which the Supreme Court decided was erroneous, reversed and remanded for new trial. On rehearing, the former decision was affirmed. The court went more thoroughly into the question as to the payee's status. The court agreed with many of the cases which hold that a payee may be a holder in due course, but did so on the ground that the results there reached should have been predicated on the doctrine of estoppel. The case is criticized adversely in $\mathrm{x}$ Wis. L. Rev. $42 \mathrm{I}$ (1922). The case was approved in Tripp State Bank v. Jerke, 45 S.D. 448 , I88 N.W. 3 I $_{4}$ ( $\mathrm{r}_{922}$ ) but in this case plaintiff, payee, was not a holder in due course because it had notice of the maker's defense at the time of purchase; affd. on rehearing 45 S.D. 580,189 N.W. $5^{14}$ (1922). Case followed in First Nat. Bank of Jasper v. Larson, 53 S.D. 262, 220 N.W. 506 (1928) and in Security Holding Co. v. Johnson, 57 S.D. 163, 23I N.W. 536 (I930). In these cases a third party procured the defendant's note, subject to a personal defense, naming plaintiff bank as payee. It has been suggested that the above cases have been the result of the specific language of Sections $I_{4}$ and I 6 of the Negotiable Instruments Law in the South Dakota draft, which differs from that of the Uniform Act, though the court made no reference to them, and the reasonableness of this basis has been disapproved. See Feezer, May the Payee of a Negotiable Instrument be a Holder in Due Course, 9 Minn. L. Rev. ror, I I9 (I925). 
course must always have acquired the instrument by negotiation. The real purpose of sub-sections (I) and (4) of Section 52 was to elaborate the idea of good faith, and its converse, bad faith. The term "negotiated" in sub-section (4) was used in the very loose general sense of transfer and not in the restricted sense of Section 30 . If this were not so the framers of the Act would not have used a form of the verb "take" in sub-section (3), where they were imposing the general requirement.

This elaboration of the idea of good faith is explainable in the light of the history of the problem here dealt with. At common law, in those cases where the evidence of bad faith was to be found on the instrument itself, the courts played a more prominent part in deciding what facts, disclosed on the instrument, did or did not establish good faith or bad faith, than they did where the evidence of bad faith lay in extrinsic circumstances. The courts spoke of instruments wherein there was evidence of bad faith as not being complete or regular. Very naturally, in the interest of certainty the framers of the Act continued recognition of this class of cases and did so in Section $5^{2}$ (I), though the content of this subsection is also in Section $5^{2}$ (3). It should be further noted that there is nothing in Section $5^{2}$ (I) which in any way suggests that the operation of the sub-section is in any way conditioned upon the manner in which the party claiming protection acquired the instrument, whether by "taking," by "negotiation," by "issuance," or by "transfer." This observation lends force to the claim that the use of the term "negotiation" in Section 52 (4) was not in the restricted sense of Section 30 . This sub-section was put in to refer to cases where the evidence of bad faith lay in extrinsic circumstances. In short, sub-section (3) was broken down into these two parts and dealt with separately. That this is so appears more fully from the fact that sub-section ( $I$ ) is further elaborated in Sections I 2, I3, and I4, and different phases of sub-section (4) are further and more specifically dealt with in Sections 55 and $5^{6}$. The whole pattern is quite consistent if the use of the term "negotiation" in Section $52(4)$ is read as a synonym for the term "took" as used in Section $5^{2}$ (3). It is quite inconsistent, if not inexplicable, if read otherwise.

The rest of the argument that a payee may be a holder in due course is readily suggested. Section $\mathrm{I}_{4}$, in dealing with incomplete instruments, provides: "But if any such instrument, after completion, is negotiated to a holder in due course, it is valid and effectual." The term "negotiation" should not be read with the meaning set forth in Section 30 , one, because that idea is not contained in Section 52 which deals specifically with the requirements of one's being a holder in due course when properly construed; two, the term "negotiation" is used in too incidental a manner 
to be given the important consequences of depriving a payee of his position as a holder in due course; three, inasmuch as Section $I_{4}$ is one of the specific instances dealt with in Section $5^{2}(\mathrm{I})$, the silence of Section $5^{2}(\mathrm{I})$, on this matter tends strongly to widen the meaning of the term "negotiation" as used in Section I4; four, the framers of the Act could hardly have introduced the idea of requiring a technical negotiation as defined in Section 30, in Section I4, and at the same time leaving it out of sections which deal with other types of incomplete and irregular paper such as are dealt with in Sections I 2 and $\mathrm{I}_{3}$, i.e., the ante-dated or post-dated instrument and the case of the insertion of a wrong date in instruments executed in blank as to date. And finally the framers of the Act would hardly have required a technical negotiation as a condition of one's being a holder in due course with respect to the one type of defense or equity, such as is set forth in Section I4 without at the same time prescribing the same requirement for all other defenses and equities which are shut off in the hands of the holder in due course.

Similarly, the argument, drawn from Section 16 , that one to be a holder in due course must not be a party immediate to the party seeking to set up the defense or equity, was not used, in the sense that if the plaintiff and defendant were immediate parties as a matter of form on the instrument, the plaintiff could by no possibility be a holder in due course. If the term "immediate," as used in Section I6, was intended to have any meaning it was used to refer to matters of substance, not form. That is, if the plaintiff and defendant were immediate parties, i.e., payee and maker, in the sense that the payee was "immediate" to the terms and conditions under which the instrument was executed by the maker, this fact would bar the payee from being a holder in due course, as indeed he would be so barred under Section 52. Again, it is hardly conceivable that the framers of the Act would deprive the payee of his position as a holder in due course with respect to the defense of non-delivery of a completed instrumentthe only defense dealt with by Section 16 -and not make a similar provision with respect to all other personal defenses, such as want of consideration, breach of contract, fraud, etc. But this they did not do, showing that the use of the expression "immediate parties" in Section 16 , was quite incidental to the main rule being laid down, i.e., that the defense of non-delivery or of conditional delivery was available against parties other than holders in due course. Most of the cases have held that the payee may be a holder in due course. ${ }^{3}$

There are several situations of fact where a third person, not a party to

3 Ex parte Goldberg v. Lewis, I9I Ala. 356,67 So. 839 (I9r4), full discussion of the cases. Payee recovers from the surety maker whose signature was obtained by the principal maker by 
the instrument, will be in possession of an instrument prior to its delivery by him to the payee. These situations may be classified in various ways. Such classifications may or may not be important in determining whether a payee should or should not be a holder in due course. It will be noted in the cases heretofore cited, particularly those wherein the payee was denied the position of a holder in due course, that the court indicates that, under other circumstances, it might or would hold that a payee would be a holder in due course. And in jurisdictions which have held that a payee could be a holder in due course, it is possible that, in later cases, the court might restrict such holdings to the class of facts which it had before it, and deny the payee the status of a holder in due course in other situations which have not as yet been presented. It is possible to hold that a payee will always be a holder in due course where he fulfills the conditions of taking for value, before maturity and in good faith. It is possible to hold the converse, i.e., that under no circumstances may the payee be a holder in due course. Between these two extremes an intermediate course is possible wherein the protection of the payee as a holder in due course will be made to depend not only upon his taking in good faith, for value and before maturity, but upon the presence of certain facts in the relation between the maker or drawer and the third party or upon the character

fraud. Followed in Dinsmore v. Cooper, 212 Ala. 45, I03 So. 460 (I925); Green v. Martin, 222 Ala. $358, \mathrm{r}_{32}$ So. 882 (r93I).

Hardy v. Ouachita Nat. Bank of Monroe, 165 Ark. 532, 265 S.W. 74 (1924). No discussion. Smith v. Ryan, I75 Ark. 23, 298 S.W. 498 (1927). No discussion. Saxon v. McGill, I79 Ark. 4I 5, I6 S.W. (2d) 987 ( I929) relying on the Massachusetts and Alabama cases. Contra cases not referred to.

Johnson v. Ulrey, 20I Cal. 456, 257 Pac. 505 (I927). No discussion. Pasadena Nat. Bank v. Shorten, 96 Cal. App. 45I, 274 Pac. $35^{8}$ (r929). No discussion. Dictum that a payee cannot be a holder in due course in Hockett v. Pacific States Auxiliary Corp., ${ }_{5}$ P. (2d) 547 (Cal. App. 1932) but on review by Supreme Court payee recovered, 23 P. (2d) 5 I 2 (Cal. I933).

Baggish v. Offengand, 97 Conn. 3I2, $x \times 6$ Atl. $6 x_{4}$ (I922). No discussion.

The state of the law in Idaho is confused due to decisions which have held both ways on the question. Three cases hold that the payee may be a holder in due course, and one holds contra. The last expression of the court states that the payee may be a holder in due course.

In Redfield v. Wells, 3I Ida. 4I5, I73 Pac. 640 (I9I8) a completed check, delivered by the drawer to his own agent for delivery to the payee, was used by the agent to pay his own debt to the payee. Held: payee was a holder in due course. The court relied on the Massachusetts, Alabama, and Montana cases. But in Consolidated Wagon \& Machine Co. v. Housman, 38 Ida. 343. $22 \mathrm{I}$ Pac. I43 (I923), where a note was signed by defendant, accommodation endorser, in blank, delivered by him to another accommodation endorser, and the note subsequently filled up and delivered to the payee in violation of his instructions, the court held that the payee could not be a holder in due course. No reference was made to the prior case or to the cases therein relied on. The court here relied on Vander Ploeg v. Van Zuuk, I35 Iowa 350, II2 N.W. 807 (1907). In Utah State Nat. Bank v. Springer, 44 Ida. 599, 258 Pac. 522 (I927) the court, without referring to the Housman case, supra, held that the payee could be a holder in due course, relying on Redfield v. Wells, supra. In McLaughlin's Store v. Copeman, 50 Ida. 214, 
of the representation made by the third party to the payee. As yet there have been too few cases involving the problem to warrant any safe conclusions as to whether certain courts are plotting the middle course. The strongest indications are merely that this may happen, and these indications are to be found chiefly in those cases where the courts have denied the payee the rights of a holder in due course and at the same time used guarded language which could be used to reach a contrary result in other situations. If this should occur, there is very little to be found in the cases which points, with certainty, to the facts that will be regarded as determining.

This middle ground has, however, been explored by certain writers and various courses charted. Professor Moore would make the protection of the payee turn on the question as to whether the third party, non-holder, was in fact a purchaser of any kind of negotiable paper, or whether he created, in the mind of the payee, the appearance of being a remitter who had purchased, from the maker or drawer, what he terms a remittable bill, note or bank draft, i.e., such an instrument which as a matter of business custom is commonly used for the purpose of making remittances to creditors, and would deny protection to the payee in a case where the third party appeared to be, not a purchaser of a remittable bill or note,

294 Pac. 523, (1930) the court said: "this court has apparently adopted the view that under certain circumstances the payee may become the holder in due course."

Drumm Const. Co. v. Forbes, 305 Ill. 303, 137 N.E. 225 (1922). Relied on Massachusetts and Alabama cases. See notes in 36 Harv. L. Rev, $75^{x}$ (1923), I8 Ill. L. Rev. 47 (1923), and 21 Mich. L. Rev. 59I (1923).

In First Nat. Bank of Herington v. Lyons Exch. Bank, roo Kan. I94, I64 Pac. 137 (I917), A obtained a draft from defendant drawer by fraud. The draft was made payable to the president of plaintiff bank and delivered to him in payment of A's note to the plaintiff bank. Held: for defendant, drawer, but on the ground that the plaintiff was not in fact a holder in due course. The court refers to the conflict of authority but takes no position thereon.

In Ladd v. Read, Ir4 Kan. X75, 2I7 Pac. 273 (I923), the court refers to the conflict of authority, takes no position with respect thereto, but states, obiter, that "the act contains nothing preventing the payee of a note, the signature to which was obtained by fraud, from acquiring it in such a way as to be able to endorse it under the ordinary equitable principles that give protection to an innocent purchaser because of his character as such, which are similar to, although not precisely the same as those relating to the holder in due course of negotiable paper."

Portland Morris Plan Bank v. Winckler, I27 Me. 306, I43 Atl. I73 (I928) (dictum).

Boston Steel \& Iron Co. v. Steuer, I83 Mass. I40, 66 N.E. 646 (I903). Leading case. Thorpe v. White, 188 Mass. 333 , 74 N.E. 592 (1905); J. G. Brill Co. v. Norton \& T. St. Ry. Co., r89 Mass. 43I, 75 N.E. Iogo (Ig05). Liberty Trust Co. v. Tilton, 217 Mass. 462 , 105 N.E. 605 (Igr4) (leading case). National Investment \& Security Co. v. Corey, 222 Mass. 543, III N.E. 357 (IgI6); Colonial Fur Ranching Co. v. First Nat. Bank of Boston, 227 Mass. I2, I 6 N.E. 73 I (19x7); McLaughlin v. Paine Furniture Co., 245 Mass. 377, r39 N.E. 542 (I923); Tremont Trust Co. v. Noyes, 246 Mass. I97, I4I N.E. 93 (I923); N. H. Nat. Bank v. Garage \& Factory E. Co., 267 Mass. 483, I66 N.E. 840 (I929); Karlsberg v. Frank, 282 Mass. 94, I84 N.E. 387 (1933). 
but an agent of the maker or drawer of either a remittable or non-remittable bill or note, if and when the applicable law of agency so dictated. ${ }^{4}$

Professor Aigler selects other facts as determining. He notes that in some cases the party who delivers the instrument to the payee is a party to the instrument, for example, a co-maker or indorser, and in delivering it to the payee diverts it from the purposes intended by the other obligors thereon. In such a case he says the payee takes the instrument as a promisee. He also notes that sometimes the party who delivers to the payee is not a party to the instrument. He may be an agent of the drawer or a remitter who has obtained the instrument for the purpose of remitting to the payee. The subsequent acquisition of the instrument by the payee is referred to as a taking by purchase. After pointing out that the law of bills and notes is derived in part from the law of contract and in part from the law of property, he concludes that where the payee takes as a promisee, as above defined, the law of contract should control and personal defenses let in, i.e., in this case the payee could not be a holder in due course. But that where the payee takes the instrument from one not a party to the instrument, the payee takes by purchase. The law of property should control and that in such case the payee could be a holder in due course..$^{5}$

On the other hand Professor Feezer finds no occasion for placing any

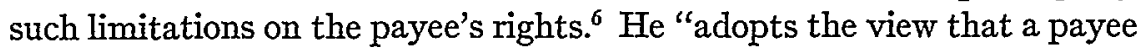
of a negotiable instrument may be a holder in due course where the circumstances are otherwise such as would bring an indorsee within the

4 In reaching this result Professor Moore has adopted a classification scheme which takes into account more of the underlying facts of the transaction. Accordingly he notes that the third party may have purchased the instrument from the drawer, i.e., a purchasing remitter, or the third person may be an agent remitter, a depositary remitter, borrowing remitter, or a thief. He concludes that "[one] who holds himself out as a purchasing remitter of almost any kind of bill or note, is granted a power to subject the signer to an obligation to the innocent payee for value, whether the third person be a defaulting agent, bailee or bailiff, diverting borrowing remitter or one who has no claim upon it by reason of no consideration, failure of consideration, conditional delivery, collateral agreement, fraud, duress, etc. . . . The scope of the power of the third person . . . . in instances where the third person appears in his authentic character of agent, depositary or borrowing remitter, is not present when he disguises himself as a purchasing remitter. ... . If, however, the purchasing remitter of a remittable bill or note, who has induced the making of the writing by false representation or duress, etc., or one who has stolen such an instrument from the signer, should represent himself as agent in disposing of it to the payee, the latter would acquire no claim against the drawer or maker. For the protection accorded innocent purchasers from those having no claims depends upon apparent ownership. The same legal consequences would follow in every case of a third person who fraudulently purchased a check from the drawer and sold it to the innocent payee." See Moore, The Right of a Remitter of a Bill or Note, 20 Col. L. Rev. 749, 758, 760 (1920).

5 Aigler, Payees as Holders in Due Course, 36 Yale L. Jour. 608 (r927).

${ }^{6}$ Feezer, May the Payee of a Negotiable Instrument be a Holder in Due Course?, 9 Minn. L. Rev. IOI (1925). 
definition of holder in due course in Section 52 of the Negotiable Instruments Law." In a note ${ }^{7}$ on this question the writer in commenting upon the distinctions suggested by Professor Aigler between the status of a payee as a promisee and the payee as a purchaser, says that

In a case of a suit by the payee against an accommodation indorser, where delivery was made directly by the maker to the payee, . . . the desirability of recognizing the possibility of a payee being a holder in due course is most apparent. And for this purpose it would seem to be immaterial whether the payee may be said to have taken as 'purchaser' or as 'promisee.'

The same writer disapproves of the suggestion made by Professor Moore that a payee should not be a holder in due course when he takes from a third party who represented that he was an agent of the maker or drawer. The writer concludes:

It is believed that the wisest course would be to place the payee on the same footing as any other taker of a negotiable instrument. As pointed out in the case between maker and payee alone, where no other parties are concerned, this would allow recovery as against maker or drawer where there has been a failure of consideration or a taking in bad faith. But it would allow recovery against a co-maker, accommodation indorser and acceptor where such defenses by maker or drawer do not exist and defenses between such parties and the drawer or maker are sought to be interposed. .... The 'remitter' situation presents an additional factor, that is, protection from defenses between drawer or maker and 'remitter.'

To the present writer the views expressed by the last two writers above referred to seem preferable. If the payee is to be a holder in due course at all he should be such on the same terms as those who take from prior holders, i.e., on proof of taking in good faith, for value and before maturity. The particular set of facts which has made possible the perpetration of the fraud by the party who delivers the instrument to the payee upon the defendant obligor should be immaterial. Once it be granted that a payee may be a holder in due course under the Act, no limitations should be imposed other than those specified in Section 52, which concerns good faith taking for value before maturity. The proposition, apparently accepted by some of the courts which have adopted the minority view, that a payee cannot be a holder in due course even though he is a good faith taker for value before maturity, and at the same time to state (obiter) that in other situations he may be a holder in due course is difficult to sustain as a matter of statutory construction. Nor are such distinctions persuasive on the matter of policy.

In this connection, however, attention should be called to Section $5^{2}$ (I) of the Negotiable Instruments Law which provides that a holder to be a holder in due course must have taken the instrument when "it is complete and regular upon its face." This provision is not an independent

${ }^{7} 36$ Yale L. Jour. 1005, 1007, 1012 (1927). 
requirement but is a special manifestation of the more general requirement that the instrument be taken in good faith. The quoted provision concerns those situations where the evidence of bad faith taking are to be found on the instrument itself, and not in extrinsic circumstances. The interpretation and application of this sub-section is, therefore, a question for the court and not for the jury. This section appears not to have been made use of in this line of cases. It is possible for a court to hold that a payee may be a holder in due course and to use Section 52 (I) as a basis for denying this status to a particular payee who has taken an instrument which, under this section, may be regarded as incomplete or irregular. Cases decided under this sub-section in other situations, not involving payees, then become usable in the payee situation. No doubt, under this sub-section, some of the cases which hold that under the facts presented the payee could not be a holder in due course, and some of the limitations suggested by the writers above referred to, could be justified.

The Committee on Amendments to the Uniform Negotiable Instruments Act, of the National Conference of Commissioners on Uniform State Laws, of which Professor Karl N. Llewellyn is Chairman, proposes that the Negotiable Instruments $\mathrm{Law}$ be so amended as to insure the holding that the payee may be a holder in due course. In the sixth tentative draft of these proposed amendments, considered by the Conference at its meeting in Grand Rapids in August, I933, the Committee proposed the following amendments. It is suggested that Section 30 be amended so as to read as follows:

An instrument is negotiated when it is transferred from one person to another in such a manner as to constitute the transferee the holder thereof. If payable to bearer it is negotiated by delivery; if payable to order it is negotiated either $(a)$ by the indorsement of the holder completed by delivery, or (b) by delivery to the payee by a person who neither himself is, nor is reasonably to be regarded as making delivery on behalf of, a sole maker, drawer, or acceptor; or $(c)$ by a drawer, maker; or acceptor purporting to issue the instrument for account of a person not a party thereto.

In Section I6 they propose that the words "between immediate parties" in the second sentence, be eliminated and that there be inserted in lieu thereof the words "to a" so that the sentence will read "As to a party other than a holder in due course" etc.

In Section 52 the proposal is to make the introduction read:

"A holder in due course is a payee or other holder who has taken the instrument under the following conditions: ...."; and to add a new sub-section (5) to read in part as follows: "In the case of a payee, that he had no notice that the person negotiating the instrument was acting wrongfully. ...."

These proposed amendments are sound and, if adopted, should remove the conflict of authority on this important question. 